\title{
Antibacterial Effect of Some Asteraceae of Southern Algeria on Nosocomial Strains of the Genus Staphylococcus
}

\section{Berbaoui $\mathbf{H}^{1^{*}}$, Cheriti $\mathbf{A}^{1}$ and Ould El Hadj-Khelil $\mathbf{A}^{2}$}

${ }^{1}$ Phytochemistry and Organic Synthesis Laboratory, University of Bechar, Bechar, Algeria

${ }^{2}$ Laboratory for the Protection of Ecosystems in Arid and Semi-Arid Zones, University Kasdi Merbah, Ouargla, Algeria

*Corresponding author: Berbaoui H, Phytochemistry and Organic Synthesis Laboratory, University of Bechar, Bechar, Algeria, Tel: (+213) 049 23 90 24; E-mail: habiba.berbaoui@hotmail.fr

Received: November 05, 2017; Accepted: December 18, 2017; Published: January 12, 2018

Copyright: @ 2018 Berbaoui $\mathrm{H}$, et al. This is an open-access article distributed under the terms of the Creative Commons Attribution License, which permits unrestricted use, distribution, and reproduction in any medium, provided the original author and source are credited.

\begin{abstract}
The study presents an interest in the antibacterial effect of some Asteraceae of southern Algeria, on nosocomial strains of the genus Staphylococcus precisely strains of two species Staphylococcus aureus and Staphylococcus epidermidis. Both species of Staphylococcus were omnipresent in nosocomial environment investigated according a to previous study. Plants tested were all shown an antimicrobial effect against the tested strains with maximum inhibition zone of $21 \mathrm{~mm}$ for Staphylococcus epidermidis for Cotula cinerea, Staphylococcus aureus shown maximum inhibition zones of $22 \mathrm{~mm}$ also for Cotula cinerea and bubonium graveolens and those for the reference strain, Staphylococcus aureus ATCC 25923, were $32 \mathrm{~mm}$ for Bubonium graveolens. Plants tested shown minimal inhibitory concentration ranging from $1 \times 10^{-3} \mathrm{~g}$ to $5 \times 10^{-4} \mathrm{~g}$. Staphylococcus strains tested were totally resistant to $\beta$ lactams with rate of $51.84 \%$ whereas their rate of resistance for cotula cinerea was only $07.21 \%$.
\end{abstract}

Keywords: Asteraceae; Staphylococcus aureus, Staphylococcus epidermidis, Nosocomial bacteria; Inhibition zone; Résistance; Antibiotics

\section{Introduction}

WHO estimates that an average of 190 million people are hospitalized each year worldwide and 9 million of them contract an infection at that time [1-6]. In Algeria, according to a national prevalence survey on nosocomial infections, led by the ministry of Health, population and hospital reform; at the hospital mustapha bacha of Algier, $8 \%$ of hospitalized patients contract a nosocomial infection [7]. Bacteria are the most common pathogens responsible for nosocomial infections [7] and major pathogens implicated are Gramnegative bacilli: 60\% Cocci Gram positive 30\% (Staphylococcus aureus) $15 \%$ [8-10]. According to a study done in 2004 on Algerian monitoring the resistance of nosocomial germs; of a total of 14400 bacterial strains isolated from hospitalized patients, 3246 are multiresistant bacteria (22.5\%), MRSA are responsible for $38.6 \%$ of nosocomial infections contracted [11]. In the present study, we are in search for medicinal plants with active antimicrobial effect on nosocomial bacteria represented by strains of the genus Staphylococcus. Plants studied were chosen from those used by the local population against infectious Diseases, supposed to have an antibacterial effect. The choice will be made after ethnobotanical survey conducted among the population of south-western Algeria on the basis of a questionnaire drawn up for the research of plants with an antibacterial effect (Table 1 and Figure 1).

\section{Rate of resistance to families of antibiotics tested}

\begin{tabular}{|c|c|c|c|c|c|c|c|}
\hline \multirow[t]{2}{*}{$\begin{array}{l}\text { Families of } \\
\text { antibiotics }\end{array}$} & \multirow{2}{*}{$\begin{array}{l}\text { S. aureus ATCC } \\
25923 \\
\text { "Diameters of } \\
\text { internal control } \\
(\mathrm{mm})\end{array}$} & \multicolumn{2}{|c|}{$\begin{array}{l}\text { Rate of Resistance of strains of } \\
\text { Staphylococcus aureus }\end{array}$} & \multicolumn{2}{|c|}{$\begin{array}{l}\text { Rate of resistance of strains of } \\
\text { Staphylococcus épidermidis }\end{array}$} & \multicolumn{2}{|c|}{$\begin{array}{l}\text { Rate of resistance of all strains } \\
\text { tested }\end{array}$} \\
\hline & & $\begin{array}{l}\text { 'resistance with } \\
\text { Critical } \\
\text { Diameters }\end{array}$ & $\begin{array}{l}{ }^{* *} \text { total } \\
\text { Résistance }\end{array}$ & $\begin{array}{l}\text { "resistance with } \\
\text { Critical } \\
\text { Diameters }\end{array}$ & $\begin{array}{l}{ }^{* *} \text { total } \\
\text { Résistance }\end{array}$ & $\begin{array}{l}\text { *resistance with } \\
\text { Critical } \\
\text { Diameters }\end{array}$ & $\begin{array}{l}{ }^{* *} \text { total } \\
\text { Résistance }\end{array}$ \\
\hline$\beta$ lactams & $24-36$ & 88.88 & 88.88 & 66.66 & 44.43 & 77.77 & 51.84 \\
\hline Aminosides & $21-29$ & 25 & 25 & 33.33 & 00 & 28.57 & 04.07 \\
\hline $\begin{array}{l}\text { Macrolides- } \\
\text { Lincosamides- } \\
\text { Streptogramin } \\
\text { (MLS) }\end{array}$ & $24-29$ & 100 & 50 & 00 & 00 & 50 & 12.5 \\
\hline Tetracyclines & $25-28$ & 100 & 100 & 100 & 100 & 100 & 100 \\
\hline
\end{tabular}


Page 2 of 5

\begin{tabular}{|c|c|c|c|c|c|c|c|}
\hline Sulfamides & $27-30$ & 68.75 & 68.75 & 66.66 & 66.66 & 67.70 & 67.70 \\
\hline Polyptides & $17-20$ & 46.33 & 27.96 & 30.33 & 3.26 & 38.33 & 13.60 \\
\hline Phenicol & $19-26$ & 00 & 00 & 00 & 00 & 00 & 00 \\
\hline Quinolones & $17-21$ & 00 & 00 & 00 & 00 & 00 & 00 \\
\hline Fosfomycine & $27-31$ & 00 & 00 & 00 & 00 & 00 & 00 \\
\hline$\%$ Résistance Globale & 00 & 47.66 & 40.06 & 32.99 & 23.81 & 40.26 & 27.74 \\
\hline
\end{tabular}

Table 1: Resistance to families of antibiotics tested.

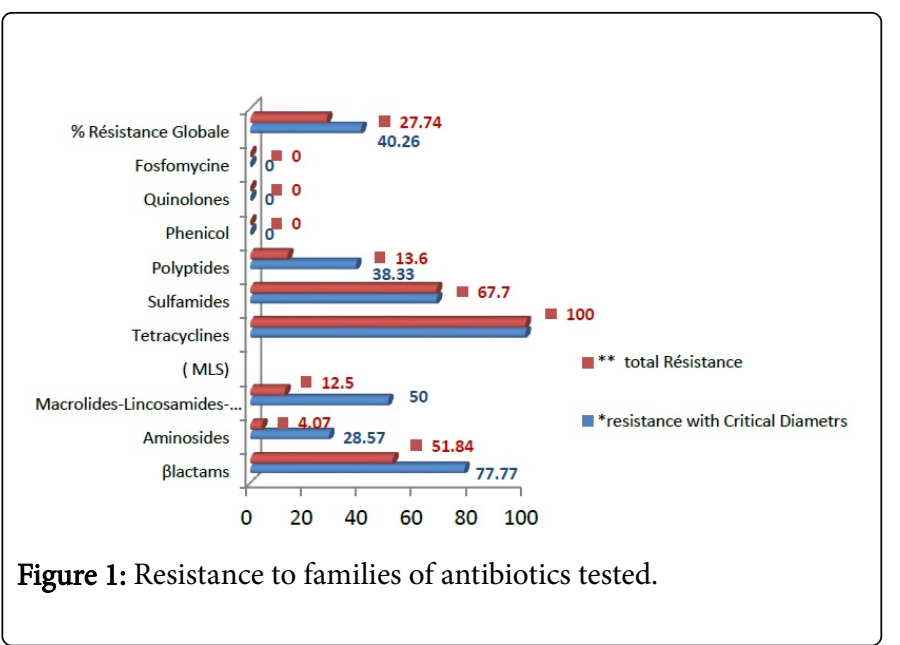

\section{Materials and Methods}

- Strains tested were collected from surfaces and air of five hospitals located in south west of Algeria in totally 100 strains.

- Sampling of surfaces: We adopted the method of wet swab on a surface of $25 \mathrm{~cm}^{2}[12,13]$.

- Sampling of air: collect of air.

- The culture medium used: blood agar and Chapman agar.

- Incubation: $37^{\circ} \mathrm{C}$ for 18 hours.

- Identification: Phenotypic of colonies, Microscopic identification: Gram stain.

- Biochemical Identification: Test Staphylocoagulase and Gallery biochemical Api for Staphylococci.

- Antibiotic resistance: We tested a range of antibiotics belonging to different antibiotics families.

- Plants tested: Cotula cinerea, Warionia saharae, Bubonium graveolens, Launaea nudicaulis and Launaea arboresens.

- Plant Extracts tested: We conducted a total of 40 extracts of five plants selected from locale practitioners typically use the aerial part of the plant without flowers and leaves separated; The number of solvents used was eight divided into two aqueous solvents: Distilled water and the hydrochloric acid, and six organic solvents: methylene chloride, chloroform, methyl alcohol, ethyl alcohol, petroleum ether and acetone.
We put in a $250 \mathrm{ml}$ flask $15 \mathrm{~g}$ of plant material to which is added 100 $\mathrm{ml}$ of solvent, the mixture is refluxed for 2 hours at a constant temperature.

The extract is filtered and the filtrate is totally dried white rotavapor.

The quantities used to impregnate the discs are drawn from the dried extract.

For the study of activity, résistance and limits of inhibition zone we used different quantities/ Disc which are: $2 \mathrm{mg}, 4 \mathrm{mg}$.

For the study of minimal inhibitory concentration we used different quantities which are: $100 \mathrm{mg}, 10 \mathrm{mg}, 4 \mathrm{mg}, 2 \mathrm{mg}, 1 \mathrm{mg}, 900 \mu \mathrm{g}, 800 \mu \mathrm{g}$ $700 \mu \mathrm{g}, 600 \mu \mathrm{g}, 500 \mu \mathrm{g}$ and $400 \mu \mathrm{g}$ from extract of distilled water.

Plants were identified at the LPSO (Phytochemistry and Organic Synthesis Laboratory University of Bechar).

*Technical Antibiogram: Concerning the technique of antibiogram, we used the method of agar diffusion standardized by the National Committee for Clinical Laboratory Standards (NCCLS) [11-14] which is an agar diffusion techniques which consists of seeding by tight grooves with a swab from a pure bacterial solution adjusted to 0.5 McFarland. and incubated at $35^{\circ} \mathrm{C}$ for 18 hours.

\section{Discussion}

It is noted that the reference strain showed no resistance to the antibiotics tested and zones shown were within in the specified limits recommended by Rahal et al. [11] whereas nosocomial strains were considerably resistant to tested antibiotics. Strains of Staphylococcus aureus were resistant with a rate of $47.66 \%$ considering critical diameters but only $40.06 \%$ shown a total resistance with negative inhibition zone $(00 \mathrm{~mm})$. Strains of Staphylococcus epidermidis were resistant to $32.99 \%$ considering critical diameters and only $23.81 \%$ shown a total resistance. Strains of both species of genus Staphylococcus tested were resistant to $40.26 \%$ considering critical diameters and $27.74 \%$ shown a total resistance. Staphylococcus aureus showed resistance to most classes of antibiotics tested. These results were consistent with those of Borg et al. [12,13], Staphylococcus epidermidis has shown a marked resistance to $\beta$ lactams. These results correlate with those of Fass et al. [14,15].

\section{Antibacterial effect of plant studied}

To interpret the results, we have taken for comparison four parameters that are: 
Citation: Berbaoui H, Cheriti A, Ould El Hadj-Khelil A (2018) Antibacterial Effect of Some Asteraceae of Southern Algeria on Nosocomial Strains of the Genus Staphylococcus. Nat Prod Chem Res 6: 302. doi:10.4172/2329-6836.1000302

Page 3 of 5

- Rate of activity of Plants extracts: Represented by the number of positive tests (presence of inhibition zones).

- Rate of resistance of Staphylococcus strains.

- Limits of Inhibition zone.

- Minimal Inhibitory Concentration.

We perform a comparison between the antibacterial effect of the plants studied with the effects of all solvents confounded for each plant (Figure 2).

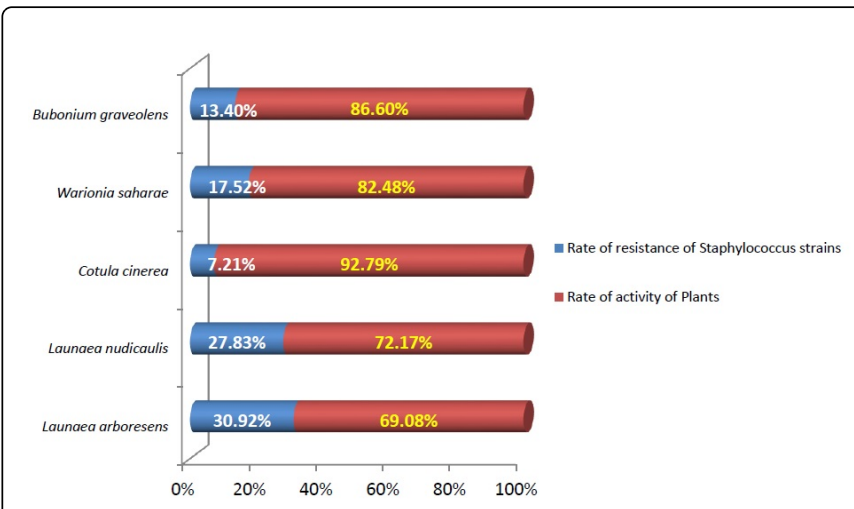

Figure 2: Activity rate of plants extracts.

All of the plants tested shown an antibacterial effect against nosocomial strains of genus staphylococcus tested but with variable rate of activity.

It is noted that Cotula cinerea has shown against the nosocomial strains the highest activity rate of $92.79 \%$ followed by Bubonium graveolens with a rate of $86.6 \%$; Warionia saharae. $82.48 \%$; Launea nudicaulis. $72.17 \%$ and Launeae arboresens. $69.08 \%$ (Figure 3) $[15,16]$.

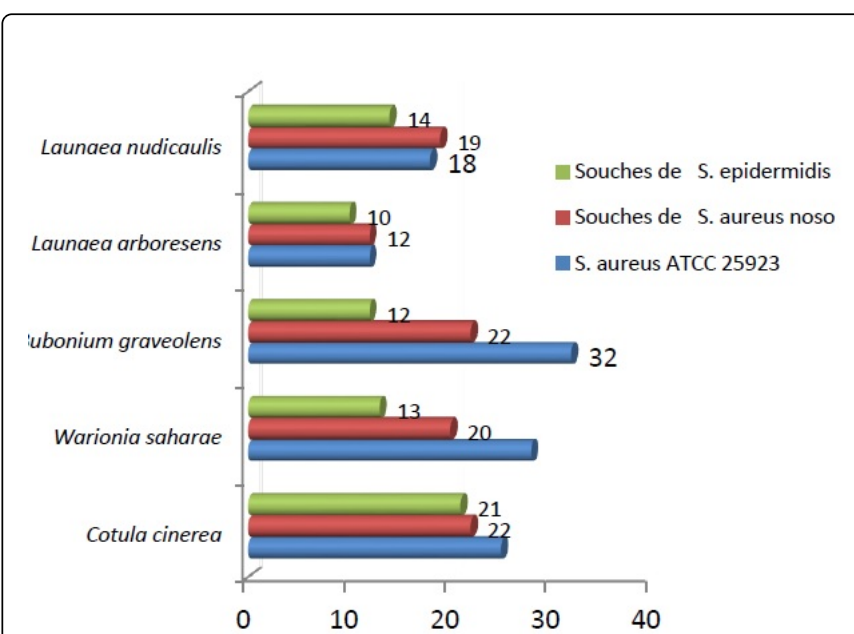

Figure 3: Limits of Inhibition zone of plants studied on the strains tested.

The maximum inhibition zones were shown by Cotula cinerea with areas of $22 \mathrm{~mm}$ to $21 \mathrm{~mm}$ for $S$. aureus and Staphylococcus epidermidis, followed by Bubonium graveolens with $22 \mathrm{~mm}$ for $S$. aureus but only $12 \mathrm{~mm}$ for Staphylococcus epidermidis. Launaea arboresens showed the smaller maximum inhibition zones for all strains tested. The other plants showed maximum inhibition zones relatively closely spaced (Figure 4) [17-20].

Concerning the reference strain maximum zones of inhibition were significantly greater for most of the plants tested (Figure 5).

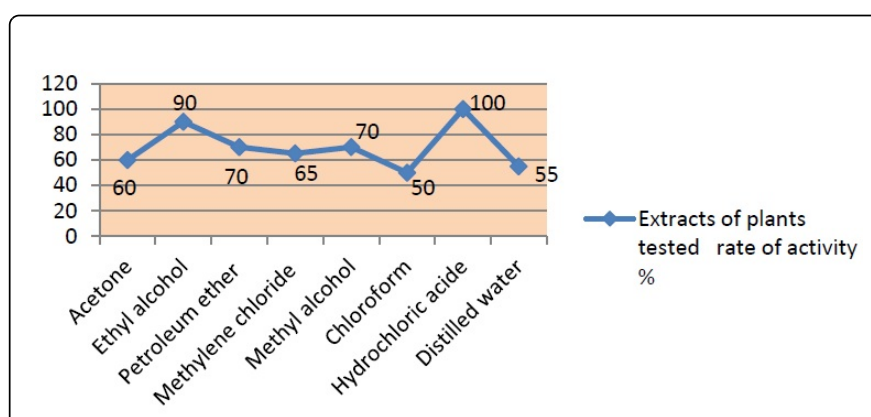

Figure 4: Extracts of plants tested.

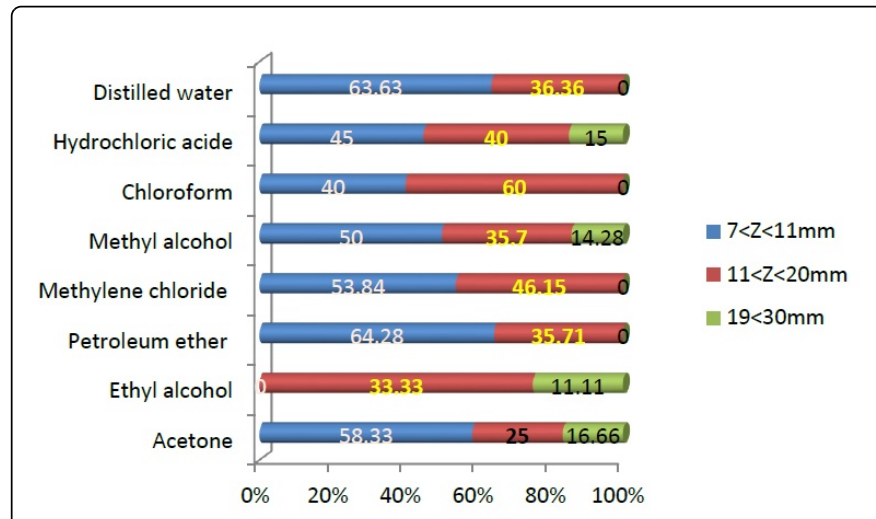

Figure 5: Rates of activity of different plants extracts against Nosocomial strains of genus Staphylococus.

Extracts shown variables rates of activity among strains tested and the highest rate was shown by extracts of hydrochloric acid with $100 \%$ with a maximum inhibition zone of $22 \mathrm{~mm}$ followed by the ethyl alcohol $90 \%$ and inhibition zone of $16 \mathrm{~mm}$ methyl alcohol extracts of a rate of $70 \%$ and an inhibition zone of $21 \mathrm{~mm}$; petroleum ether:70\% and $18 \mathrm{~mm}$; Dichlorométhane:65\% and 21\% Acetone:60\% and $21 \mathrm{~mm}$, Distilled water:55\% and 14\% Chloroform:50\% and $19 \mathrm{~mm}$ (Figure 6).

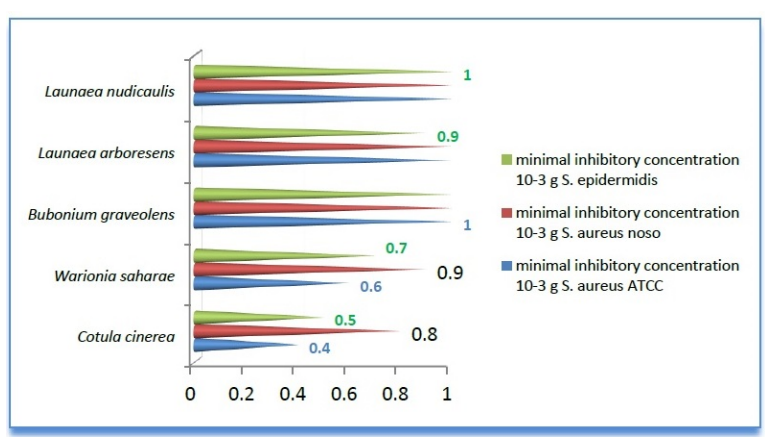

Figure 6: Minimal Inhibitory Concentration. 
Page 4 of 5

Plants tested shown minimal inhibitory concentration ranging from $1 \times 10^{-3} \mathrm{~g}$ to $5 \times 10^{-4} \mathrm{~g}$. Cotula cinerea showed the smallest minimal inhibitory concentration of $5 \times 10^{-4} \mathrm{~g}$ followed by Warionia saharae with a concentration of $7 \times 10^{-4} \mathrm{~g}$ Launaea arboresens with a concentration of $9 \times 10^{-4} \mathrm{~g}$ and the rest of plants with the concentration of $1 \times 10^{-3} \mathrm{~g}$ (Figure 7).

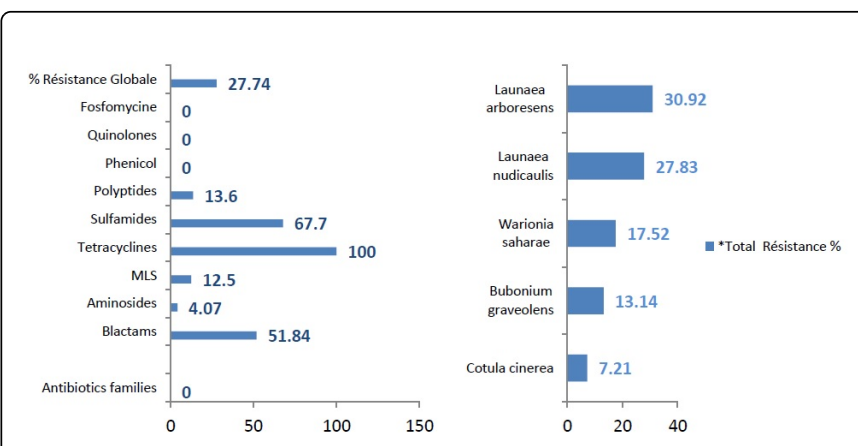

Figure 7: Antibactérial Activity of Plants extracts and Antibiotics families.

Staphylococcus strains tested were Resistant to tetracyclines, Sulfamides and $\beta$ lactams with successive rates of $100 \%, 67.70 \%$ and $51.84 \%$ whereas their rates of resistance for plants tested were included between $30.92 \%$ concerning Launaea arboreseens and only a rate of $07.21 \%$ for Cotula cinerea.

\section{Conclusion}

Strains of both species of genus Staphylococcus tested were resistant to $40.26 \%$ considering critical diameters and $27.74 \%$ was totally resistant with negative inhibition zone. Whereas the reference strain showed no resistance to antibiotics tested.

All of the plants tested shown an antibacterial effect against nosocomial strains of genus staphylococcus tested but with variable rate of activity. Cotula cinerea has shown against the nosocomial strains the highest activity rate of $92.79 \%$.

The maximum inhibition zones were shown by Cotula cinerea with areas of $22 \mathrm{~mm}$ to $21 \mathrm{~mm}$ for $S$. aureus and Staphylococcus epidermidis.

Extracts shown variables rates of activity against strains tested and the highest rate was shown by extracts of hydrochloric acid with $100 \%$ with a maximum inhibition zone of $22 \mathrm{~mm}$.

Plants tested shown minimal inhibitory concentration ranging from $1 \times 10^{-3} \mathrm{~g}$ to $5 \times 10^{-4} \mathrm{~g}$ and Cotula cinerea showed the smallest minimal inhibitory concentration of $5 \times 10^{-4} \mathrm{~g}$.

Staphylococcus strains tested were Resistant to tetracyclines, Sulfamides and $\beta$ lactams with successive rates of $100 \%, 67.70 \%$ and $51.84 \%$ whereas their rates of resistance for plants tested were included between $30.92 \%$ concerning Launaea arboreseens and only a rate of $07.21 \%$ for Cotula cinerea.

Cotula cinerea has shown the highest antibacterial activity against strains of staphylococcus tested.

\section{Acknowledgments}

We Acknowledge A. Cheriti and A. khelil Ouald El hadj for their precious guidance, excellent technical assistance, and révision of the document. We also acknowledge the assistance of the staff of the investigat hospitals. We also acknowledge A. Gherdine for technical assistance, not forgetting the staff LPSO (Phytochemistry and Organic Synthesis Laboratory University of Bechar, 08000, Bechar Algeria).

\section{References}

1. Berbaoui H, Cheriti A, Ould el Hadj-khelil A (2014) Distribution and polymorphism of nosocomial strains of the genus Staphylococcus isolated in the Bechar region; 4th Phytochem and BioSub Conference (4th PCBS) and 1st Algerian Days on Natural Products (1st ADNp).

2. Gary R, Brenniman R, Allen J (1993) Impact of repackaging hazardous (infectious) hospital waste on the indoor air quality of a hospital. Sci Tot Environ 128: 141-149.

3. Ekhaise FO, Ighosewe OU, Ajakpovi OD (2008) Hospital Indoor Airborne Microflora in Private and Government Owned Hospitals in Benin City. World J Med Sci 3: 19-23.

4. Carvalho KS, Melo MC, Melo GB, Gontijo-Filho PP (2007) Hospital surface contamination in wards occupied by patients infected with MRSA or MSSA in a Brazilian university hospital. J Basic App Pharmaceu Sci 28: 159-163.

5. Ensayef S, Shalchi AS, Sabbar M (2009) Microbial contamination in the operating theatre: A study in a hospital in Baghdad. East Mediteran Health J 15: 219-223.

6. Pibiri MC (2006) Microbiological sanitation of the air and ventilation systems using essential oils. Thesis No 3311, Swiss federal institute of technology, p: 177.

7. Benichou J, Boyer JM (2003) Mastery of nosocomial infections in respiratory services. Facul Med Pharm Rouen.

8. Beziaud N, Pavese P, Barnoud D, Laval G (2008) Bacterial infections in palliative care: antibiotic and therapeutic limitations. Medical Press, p: 10.

9. Berrebi W (2004) Diagnostics and Therapeutics: From symptom to prescription. Practical Guide. Estem, p: 1298.

10. Bossuyt X, Humbel R, Mewis A, Servais G, Tomasi JP (2006) External evaluation of the quality analysis in clinical biology: microbiology/ serology/parasitology. Global Report, p: 6.

11. Rahal K, Belouni R, Tali Maamar H, Benslimani A, Missoum MFK, et al. (2004) Monitoring network of bacterial resistance to antibiotics, WHO project. 4ème Evaluation Report, p: 144.

12. Borg MA, Scicluna E, Kraker M, Van de Sande-Bruinsma N, Tiemersma E (2006) Antibiotic resistance in the south-eastern MediterraneanPreliminary results from the Armed Project. Euro Surveill 11: 164-167.

13. Araj GF, Uwaydah MM, Alami SY (1994) Antimicrobial susceptibility patterns of bacterial isolates at the American University Medical centre in Lebanon. Diagn Microbiol Infect Dis 3: 151-158.

14. Fass RJ, Helsel VL, Barnishan J, Ayers LW (1986) In vitro susceptibilities of four species of coagulase negative Staphylococci. Antimicrob Agents Chemother 30: 545-552.

15. Lei P (2001) A Fibrinogen-Binding Protein from Staphylococcus epidermidis. Thesis-Kongl Carolinska Medico Surgical Institute, p: 55.

16. Savey A, Carlet JC (1999) Clin-Ouest Coordination Centre for the Fight against Nosocomial Infections: Recommendations for environmental controls in health institutions, France, p: 57.

17. Meunier O, Hernandez C, Piroird M, Heilig R, Steinbach D, et al. (2005) Bacteriological sampling of surfaces: importance of the enrichment step and the choice of culture media. Annals Biol Clin 63: 481-486.

18. Jorgensen JH, Turnidge JD, Washington JA (1999) Antibacterial susceptibility tests: dilution and disk diffusion methods. Manual Clin Microbiol, pp: 1526-1543.

19. Wayne PA (2002) National committee for clinical laboratory standards. Performance standards for antimicrobial disc susceptibility testing, p: 12. 
Citation: Berbaoui H, Cheriti A, Ould El Hadj-Khelil A (2018) Antibacterial Effect of Some Asteraceae of Southern Algeria on Nosocomial Strains of the Genus Staphylococcus. Nat Prod Chem Res 6: 302. doi:10.4172/2329-6836.1000302

Page 5 of 5

20. Rahal K, Tali Maamar H, Benslimani A, Belouni R, Missoum MFK (2000)

Monitoring of bacterial resistance to antibiotics: WHO project:

Evaluation Report, p: 123. 